\title{
A Case Study of Higher Education Reform in Russia Institutional Change at Ryazan State Pedagogical University
}

\section{Don Hossler}

Don Hossler is professor of educational leadership and policy studies and executive associate dean of the School of Education at Indiana University. This paper is an abbreviated version of a chapter that will appear in a book on higher education reform in postcommunist countries, edited by Paula Sabloff and published by Garland Press.Address: School of Education, Indiana University, Bloomington, IN 47401, USA.

$\mathrm{S}_{\mathrm{i}}$ ince 1986, the higher education system in Russia has experienced many significant changes. The formal educational reforms for higher education planned in 1986 were intended to raise academic standards, eliminate $V U Z y-$ Russian for institutions of higher education-introduce more accountability, develop admissions targets related to actual labor market demands, and provide more individualized curricula.

Two of the most significant developments for Russian universities are their sources of funding and the nature of their relationships with students. Under the Soviet system, $V U Z y$ received all of their funding from the national government. The funding lines were so direct and specific that Russian $V U Z y$ did not have senior administrators for financial matters. In contrast, current national appropriations barely cover faculty salaries and student stipends. Funds for research, equipment, capital expenditures, and maintenance must come from other sources.

\section{Two of the most significant develop- ments for Russian universities are their sources of funding and the nature of their relationships with students.}

Relationships between institutions and prospective students have also changed. Graduates of $V U Z y$ are no longer guaranteed jobs. In 1994, 30 percent of all $V U Z y$ graduates were unable to find jobs. High school students and their families find themselves trying to decide which university to attend and what area of specialization to select with little previous experience in making such decisions.

In the spring and summer of 1995 I had the opportunity to conduct a case study of organizational change at Ryazan State Pedagogical University (RSPU). RSPU is in the city of Ryazan-200 kilometers southeast of Moscow. The capital of the region, the population of Ryazan is approximately 600,000 . Key findings related to these quetions are summarized in the following section.

\section{FUNDING}

In 1984, RSPU received sufficient funds from Moscow to pay for 16 budgetary lines including: salaries, student stipends, construction of new facilities, repair and maintenance, library books, consumable supplies, equipment, social activities of students and faculty, and summer camp for staff and students. By 1992 there were only enough funds to cover salaries and student stipends. These changes have occurred in a social context in which there is no tradition of individual or corporate philanthropy. Although VUZy have instituted tuition payments for some students, they are not significant and most families lack sufficient income to pay tuition.

\section{By 1992 there were only enough funds to cover salaries and student stipends.}

By 1994 several changes were evident at RSPU. Seventy percent of RSPU funds continued to come from the national government, but 9 percent of the university's revenue came from tuition-paying students and fees collected for taking entrance examinations and college preparatory classes. External grants and contracts from foreign countries and agencies accounted for nearly 15 percent of all revenue in 1994. The Ryazan region provided about 2 percent of the university's budget in interest-free loans. The city of Ryazan gave funds to the university equal to nearly 1 percent of its total revenues. The remaining 2 percent of RSPU's revenues in 1994 came from contracts with local business firms, city government, and other local parties.

Organizational goals and activities have changed to reflect these new sources of revenue. According to senior administrators, finding money and material resourcesequipment, and supplies-has become the major responsibility of senior administrators. They have had to stress the importance of fundraising activities to all academic administrators. Prior to perestroika, meetings of administrators and faculty seldom centered on economic issues; now financial affairs dominate meetings. RSPU now has a vicerector for economic and international affairs. Both sets of activities have the same purpose: to secure additional rev- 
enue.

\section{STUdents And Markets}

In interviews I was told consistently that foreign languages-especially English and German-business degree programs, law, and computer science were the most popular fields of study. Jobs as secretaries working in international firms, as nannies for wealthy families, and positions at MacDonald's or other firms that serve large numbers of foreigners were prized because of higher pay and job stability.

Attending high-status institutions-like Moscow State University - is no longer as desirable for students living in other parts of Russia as it once was. Students and parents expressed concerns about attending a $V U Z$ in any of the large cities because of the high cost of living and crime rates. Because graduates are no longer assigned to jobs in all regions of Russia by the national government, there is pressure on VUZy to be more responsive to the interests and concerns of students and to meet the needs of the regional labor market.

In response to these changes RSPU was
developing new academic programs
that will be attractive to students and
strengthen the academic programs al-
ready in place.

In response to these changes RSPU has been developing new academic programs that will be attractive to students and strengthen the academic programs already in place. It recently added a law school. It has strengthened a specialization in computer science and is adding a specialty in computer science and English. The university had also been working with an American university to develop an undergraduate degree in business.

RSPU was among a small number of universities that have developed optional second areas of specialization or minors. These new minors are more in tune with emerging fields of employment: 87 percent of graduating students in 1994 had taken at least one of the new specialties. Specialty options included such areas as physical therapy, public relations, and sports training.

To assure a steady supply of students and additional revenue RSPU has also initiated college preparatory courses for local youth. Some of these courses are offered in the evenings and on weekends so that young people from outlying villages can come to Ryazan for these year-long courses.

RSPU has started to charge tuition for about 15 to 20 percent of enrolled students. The national government funds the university for an established number of students to enroll. Students who qualify for admission this way must earn high entrance exam marks and receive a governmentfunded stipend. RSPU also sets aside an additional number of seats for students to enroll who get acceptable-but not outstanding-entrance scores. Students who have a wealthy sponsor who can pay tuition fees are then accepted to fill these limited number of additional seats. RSPU has also started to provide more written information about their programs to local high schools.

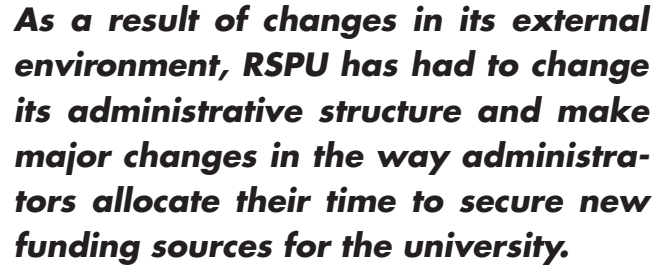
environment, RSPU has had to change its administrative structure and make major changes in the way administrators allocate their time to secure new funding sources for the university.

\section{Conclusions}

As a result of changes in its external environment, RSPU has had to change its administrative structure and make major changes in the way administrators allocate their time to secure new funding sources for the university. Resource dependency theory provides a good framework to analyze the changes taking place within RSPU. In addition, the university has made changes in its curriculum and testing procedures, and devised other strategies in order to reach out to students in new ways that implicitly recognize an emerging market relationship between students and the university. This case study was also conducted at a VUZ that appears to be successfully responding to changes in the external environment. Institutional case studies such as this provide important insights into the effects of social and educational changes on institutions of higher education in Russia. 